\title{
Violence: a challenge for public health and for all
}

\author{
A Concha-Eastman
}

Violence is both a public health and a social problem. Although there is not only one type of violence nor a unique concept of what it means, the following concept has gained consensus, particularly among those working intersectorally with a public health approach: "Violence is an intentional use of physical force against another person or against oneself, which either result in or has a high likelihood of resulting in injury or death". "This definition has two main components: the intention and the harm it produces. It is also focused on the event itself: hence it is either case or victim oriented, as in many public health situations. Its usefulness relies upon the possibility of linking the case with the specific circumstances that led to or ended in violence.

Some common cases are worth illustrating: a woman with bruises on her face; a child with a burn on their back; a young man with a firearm generated wound, an adult killed in an assault on a bank. We ask ourselves: were they accidental? The answer is no. They were all intentionally inflicted. They were man/woman made, on purpose. So, the challenge for health professionals is not only to carry out a proper and adequate bandaging, stitching or operating on the cases who look for care at health facilities. Actually, the challenge goes beyond the emergency unit. The challenge is how to develop preventive interventions to avoid the occurrence of cases such as these.

In doing so, there are many problems to face. To start with, it is necessary to state that good and reliable data, to measure the burden and trend of the problem, are required worldwide. Although the data are not complete, it has been established that the Americas has the highest rate of homicide in the world, higher than 15 per $100000 .^{2}$ Countries of the Americas have been reporting around 300000 registered deaths attributable to external causes every year to the Pan American Health Organisation over the past few years. In the 1999 PAHO report (which includes the latest available country data for one year between 1995-98), intentional homicide accounted for about 120000 deaths (40\%), and suicides for 56000 $(19 \%) .^{3}$ Data differ substantially between countries. Considering that homicides rate higher than 10 per 100000 inhabitants, and that this cause of death is difficult to control by conventional measures, ${ }^{4}$ it must be pointed out that in more than 12 countries in Latin America and the Caribbean (LAC) that this is the situation. El Salvador and Colombia are the countries with the highest homicide rates (90 and 65 per 100000 respectively for 1999). However, others like Mexico, Brazil, Jamaica, Honduras, Guatemala, Venezuela and others have homicide rates between 12 and 45 per 100000 inhabitants. Most of these cases occur in urban environments. The four most populated countries account for $84.2 \%$ of the total number of homicides in the Americas: they are Brazil (37 128), Colombia (27 620), the United States (20 634) and Mexico (15 616), where $71 \%$ of the population of the continent lives. If the US is excluded, these three LAC countries, where $60 \%$ of the population of the continent live, account for $82 \%$ of homicides.

Surveys have established that $30-60 \%$ of women in relationships are victims of violence perpetrated by their partners. ${ }^{5} \mathrm{~A}$ similar finding from the Multicenter Study on Cultural Norms and Attitudes towards Violence (known as the ACTIVA study) applies to children abused by their parents (See Rev Panam Salud Pública/Pan Am J Public Health, 1999:5(4/5)). These sets of data, however, do not reflect the real magnitude of domestic violence. Indeed a lot of cases are not registered either because children or women do not look for care or because the cause of the injury is not registered. The ACTIVA study also identified differences between cities, regarding the victimised subject's attitudes, and practices, as well as in the magnitude and nature of victimisation. ${ }^{6}$

Young unemployed people, with little or no skills, form neighbourhood gangs as a response to a society that provides few opportunities. In El Salvador, Honduras, Nicaragua and Guatemala members of these gangs, known as "maras", are seen as aggressors and promoters of social violence. It is estimated that about 30000 young people are involved in these types of activities in El Salvador. Other expressions of violence are domestic violence against women, boys/girls and the elderly, as well as juvenile violence, all of which leave victims with psychological sequelae, affect personal development and, to a great extent, the family and social organisation.

The type of violence and its characteristics varies from country to country and is also linked to changes in the social and political context. For instance, in the former Eastern European countries social violence has grown after the fall of communism. Social violence emerged in Central American countries after peace agreements. In the US a lot of concern is placed on shootings that quite often happen in schools or public places. In Brazil the media have shown police brutality against street children as an important issue. In Colombia the civil war, its massacres, the narcotic trafficking and common delinquency are major problems with violence.

Violence also has a direct effect in the economic and social development of countries. A study by the Inter American Development Bank, in six Latin American countries during 1996-97, found that on average $14.8 \%$ of the 
Table 1 GPD spending percentage on security and violence by country

\begin{tabular}{ll}
\hline Country & $\begin{array}{l}\text { \% of GDP } \\
\text { spending on } \\
\text { security and } \\
\text { violence }\end{array}$ \\
\hline Brazil & 10.5 \\
Colombia & 24.7 \\
El Salvador & 24.9 \\
Mexico & 12.3 \\
Peru & 5.1 \\
Venezuela & 11.8 \\
\hline
\end{tabular}

GDP is spent on security and violence control. The GDP spending percentage by country is shown in table 1.

The study took into consideration direct costs by governments and the private sector, health expenditures, intangibles, and transfers. ${ }^{7}$ Without the problem of violence, this spending could be used in social or development projects.

Most researchers and scholars agree that violence is a multicausal phenomenon. Different models to explain how and in what circumstances violence occurs have been developed. In the ACTIVA study a model developed by McAlister was applied: it takes into account psychological and social processes that influence people's behaviour towards violent events. ${ }^{8} 9$ Moser et al use an ecological model that incorporates structural, institutional, interpersonal, and individual contributing factors to explain violent behaviour. ${ }^{10}$

Despite the fact that there are cases in which the individual biological factors have to be taken into account as causes of misconduct, I do not include that level when talking about social violence. An interconnected three tiered model to explain social violence can be presented. All tiers are interconnected and when they interact synergistically promote violence. At the top there are structural factors, which refer to macro level aspects such as socioeconomic inequality, poverty, corruption at the level of government and leaders, demographic shift, lack of social and ethical values, human rights violations, government instability, and rapid urbanisation with no opportunities to those displaced from rural to urban areas. Society as a whole is a receptor of changes in these factors.

The second tier refers to institutional factors. These are factors that influence negative attitudes by citizens towards institutions. Weak institutions that do not capture or punish perpetrators of violence lead to higher levels of impunity that make it easier for criminals to act. A lack of confidence in the police and judiciary systems gives people a sense of insecurity and lack of protectionopening the doors for vigilante actions. A low quality of education precludes people from using alternative conflict resolution skills rather than resorting to violence. A lack of parents and parenting guidance, as well as family breakdown leaves children with no models of behaviour to follow.

Finally, there are facilitating or direct factors, which, under specific circumstances facilitate the occurrence of violent events. Alcohol consumption as well as the use and misuse of narcotics have been strongly associated with homicide, violent injuries, and domestic violence. These factors, as well as the possession and carrying of guns are not classified as basic causes. However, there is evidence to suggest they play an important facilitating part and as such, they trigger violent reactions, with more lethal consequences. A recent publication points out the effectiveness of a gun carrying ban in lowering homicide rates. ${ }^{11}$ An additional factor relates to the role of the media in extolling violent behaviour and the creation of role models that encourage violence through false heroes and bandits.

The evolution of violence control and prevention has had three "historical moments" in the ways in which governments and society have tackled violence. Firstly, the police and the judiciary system have traditionally been in charge of control and deterrence of violence. They are usually given the responsibility of capturing and punishing delinquents and criminals. Governments and society have relied on them for control and prosecution of violent persons.

A second "historical moment" in approaches to dealing with violence has been observed during the past $20-25$ years. This period is based on theoretical approaches that explain violence as a multi-faceted phenomenon, and consequently understand the alternative strategies to repression, jailing, and deterrence should be added or even substituted. These newer views of prevention and control have been supported by the scientific community and derive from the principles of primary, secondary and tertiary prevention, as in public health.

Finally, a marked escalation of violence has eroded the social values necessary for coexistence and respect for other peoples' rights, including the right to live. Violence has negative effects on both social and human capital. Today, in many countries almost every citizen has suffered the consequences of violence either directly or indirectly. This has substantially changed peoples' beliefs and attitudes on conflict resolution. Participation and commitment from all citizens, and their association with institutional programmes is essential in reducing violence. I call this a third period, which has clearer visibility from five years ago, in which social balance and peaceful environments need to be achieved through stronger community organisations and direct community participation. ${ }^{12}$ The challenge to reduce violence concerns us all.

Communities suffer violence as a vicious circle where causes and events are feeding themselves. Paying attention only to the effects of violence will make it more difficult to break such a cycle. The following basic principles must be taken into account when dealing with violence prevention projects. Firstly, we must look for the multi-causality of violence, then invest in prevention rather than in reprisal. Secondly, we have to look at the strength of peoples' commitment at all levels of the civil society to methods of preventing violence through community empowerment. Thirdly, we must not make any discrimination between the beneficiaries because of their ethnic origin, political beliefs, religious preferences, gender or sexual orientation. Fourthly, we must look at strength capacity building for violence prevention in sectors not traditionally working in this field, such as health, education and media agencies. Fifthly, last but not least, we must consider the relations between violence and economic and social development. 
For violence prevention it is necessary to:

- Create mechanisms to elaborate, design and implement national plans for the prevention and control of violence through surveillance systems, prevention projects, and provision of care and resocialisation for the victims of injuries and violence;

- Help in the design and definition of strategies to prevent violence;

- Generate commitment from governments and the society at large, to tackle the problem of violence with a preventive perspective;

- Support the design of national and municipal plans for the prevention of violence;

- Create or strengthen intersectorial committees for the surveillance of injuries and violence in each country at national and municipal levels and organise networking;

- Identify successful interventions and foster the development of community based projects;

- Evaluate existing policies and legislation on injury prevention and control, for each country;

- Establish mechanisms to coordinate the care and rehabilitation of victims of violence;

- Develop modules for comprehensive care of the victims of violence that include not only medical care, but also preventive aspects and psychosocial rehabilitation.
Public health commitment in studying and preventing violence is a challenge to be faced by society as a whole to create better environments for present and future generations.

1 Rosenberg ML, O'Carroll PW, Powell KE. Let's be clear. Violence is a public health problem. $f A M A$ 1992;267:3071-2.

2 Fajnzylber P, Lederman D, Loayza N. Determinants of crime rates in Latin America and the world. Latin American and Carrates in Latin America and the world. Latin American and Car-

$3 \mathrm{PAHO} / \mathrm{SHA} / 99.01$. Health situation in the Americas. Basic Indicators. 1999. Washington, DC.

4 Ratinof L. Delincuencia y paz ciudadana. En: Hacia un enfoque Ratinof L. Delincuencia y paz ciudadana. En: Hacia un enfoque
integrado del desarrollo: ética, violencia y seguridad ciudadana. Encuentro de reflexión. Washington: BID, 1996.

5 Heise LL, Pitanguy J, Germain A. Violence against women. The hidden health burden. World Bank discussion paper no 255. Washington, DC: The World Bank, 1994.

6 Cruz JM. La victimización por violencia urbana: niveles y factores asociados en ciudades de América Latina y 1999;5:259-67.

7 Buvinic M, Morrison A, Shifter M. Violence in Latin America and the Caribbean. A framework for action. Washington, DC: World Bank Discussion Papers, no 255, 1994.

8 Fournier M, De Los Rios R, Orpinas P, Piquet-Carneiro L. Estudio multicéntrico sobre actitudes y normas culturales frente a la violencia (ACTIVA): metodología. Rev Panam Salud Pública/Pan Am f Public Health 1999;5:222-31.

9 McAlister A, Velez LF. Behavioural sciences concepts in research on the prevention of violence. Rev Panam Salud research on the prevention of violence. Rev Pana

10 Moser C, Lister S, Mcllwaine C, et al. Violence in Colombia: building sustainable peace and social capital. Washington, DC: building sustainable peace
The World Bank, 1998.

11 Villaveces A, Cummings P, Espitia VE, et al. Effect of a ban on carrying firearms on homicide rates in two Colombian cities. FAMA 2000;283:1205-9.

12 Sampson RJ, Raudenbush SW, Earls F. Neighbourhoods and violent crime: a multilevel study of collective efficacy. Science 1997;277:918-24. 